\title{
Peertechz
}

Short communication

\section{Determining the tracheal tube size by echography}

\section{Hector R Diaz Aguila*}

Intensive Care Unit, University Hospital of Sagua la Grande, Sagua la Grande, Villa Clara, Cuba

Received: 19 October, 2020

Accepted: 28 October, 2020

Published: 29 October, 2020

*Corresponding author: Hector R Diaz Aguila, Intensive Care Unit, University Hospital of Sagua la Grande, Sagua la Grande, Villa Clara, Cuba, Tel: 53 42663602; E-mail: hectordiaz@infomed.sld.cu ORCID: https://orcid.org/0000-0003-3867-1080

Keywords: Echography; Tracheal canulation; Tracheal tube size

https://www.peertechz.com

\section{Abstract}

In this paper we described the importance and how is performed the echography for measuring the diameter of trachea for determining the proper tracheal tube size before intubation.

\section{Introduction}

At the present, about 50 million tracheal intubations are performed globally per year.

Determining the tracheal tube size that will be inserted in the airways is crucial. They have been described some methods for that task: charts and mathematical formulas.

Such instruments are of doubtful utility in adults, that's why the intubation of airways demands a challenge [1].

Assessing the traverse diameter of the trachea at the level of the cricoid cartilage can be done by means of several images methods: X-rays, computed tomography scan, magnetic resonance imaging and echography.

A study of Gupta K and its colleagues in 2012 have utilized US to determine ET tube size and have deeply analyzed the correlation between this imaging technique and the choice of the "correct" ET tube [2].

Echography has become an essential tool in medicine, by it use the diameter of the trachea can be easily measured for determining the proper endotracheal tube size to be inserted [3].

\section{Main indication for tracheal intubation [4]}

- Airways obstruction
- Airways protection against aspiration

- Apnea

- Bronchoscopy

- Cardiac arrest/ Cardiorespiratory reanimation maneuvers

- Conscious impairments (Glasgow Coma Score $<8$ points)

- ENT or maxillofacial shared airway procedures

- Foreign bodies removal

- General anesthesia

- Instillation of medications

- Mayor head, neck and chest trauma

- Multiple organ failure

- Oxygenation failure

- Respiratory distress

- Tracheal/bronchial clearance

- Unable to protect own airway

- Ventilatory failure 


\section{Contraindications for tracheal intubation [4]}

- Airway obstruction by a foreign body above the point where the tube will be passed.

- Inadequate training in intubation or lack of appropriate equipment.

- Severe caution should be observed in patients with cervical spine fractures, where in-line stabilization should be performed in order to prevent spinal cord damage or transection.

\section{How the echographic tracheal diameter can be determi-} ned

The tracheal diameter was estimated with standard resolution B-mode ultrasonography with a linear probe of small footprint ( $40 \mathrm{~mm}$ length, frequencies 7 to $15 \mathrm{MHz}$ ) positioned on the midline with their head extended and neck flexed (the sniffing position) [Figure 1].

The transverse air column diameter was measured at the level of the cricoid cartilage; it is considered the tracheal diameter [5]. [Figure 2].

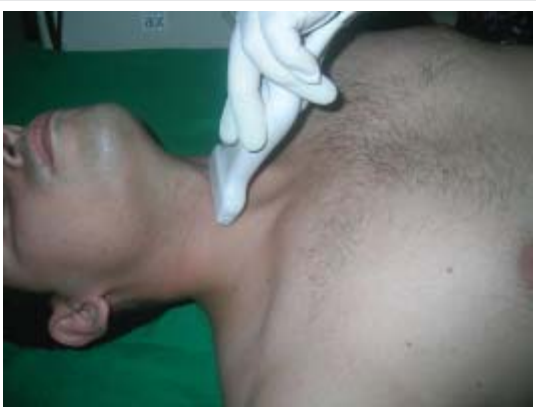

Figure 1: Probe position for the ultrasound of trachea.

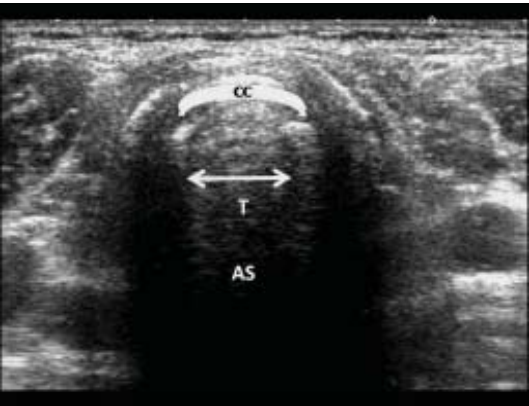

Figure 2: Assessment of the traverse diameter of the column of air at the level of the cricoid cartilage

Cc: Cricoid cartilage; T: tracheal traverse diameter; AS: Posterior acoustic shadow.

\section{Conclusion}

Echography is a secure trustworthy noninvasive reproducible method for assessing of the tracheal diameter for selection the properly endotracheal tube size for clinical use.

\section{References}

1. Karmali S, Rose P (2020) Tracheal tube size in adults undergoing elective surgery - a narrative review. Anaesthesia 75: 1529-1539. Link: https://bit.ly/37Sc067

2. Gupta K, Gupta PK, Rastogi B, Krishan A, Jain M, et al. (2012) Assessment of the subglottic region by ultrasonography for estimation of appropriate size endotracheal tube: A clinical prospective study. Anesth Essays Res 6: 157160. Link: https://bit.ly/35Ee22h

3. Hatfield A, Bodenham A (1999) Ultrasound: An emerging role in anaesthesia and intensive care. Br J Anaesth 83: 789-800. Link: https://bit.ly/3jBnKaz

4. McGuire B, Hodge K (2019) Tracheal intubation. Anaesthesia and Intensive Care Medicine 20: 681-686. Link: https://bit.ly/370IN8w

5. Zhang J, Teoh WH, Kristensen MS (2020) Ultrasound in Airway Management. Curr Anesthesiol Rep. Link: https://bit.ly/3kCkWLE

\section{Discover a bigger Impact and Visibility of your article publication with}

\section{Peertechz Publications}

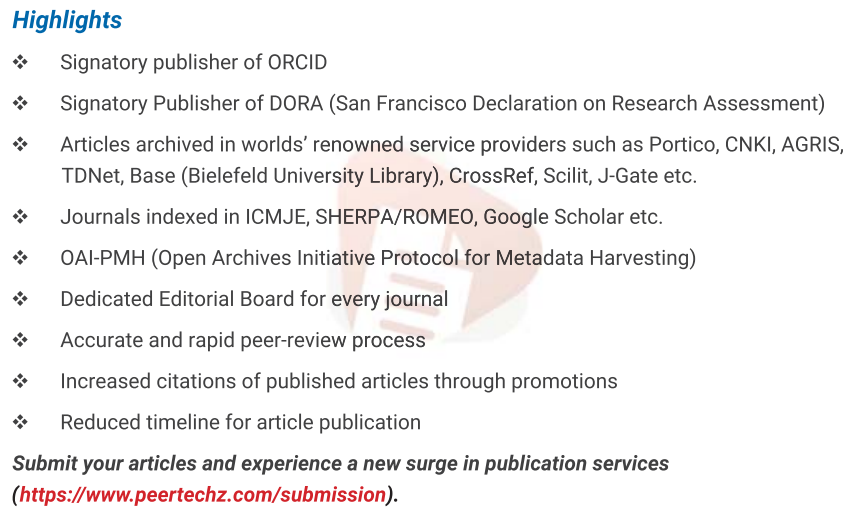

Peertechz journals wishes everlasting success in your every endeavours.

Copyright: @ 2020 Diaz Aguila HR. This is an open-access article distributed under the terms of the Creative Commons Attribution License, which permits unrestricted use distribution, and reproduction in any medium, provided the original author and source are credited. 